\title{
Арабский географ начала $X$ в. Ибн ал-Факих о византийской феме Халдия: к вопросу о военной политике Константинополя в западно-кавказских и армянских владениях на рубеже VIII-IX вв.
}

\author{
Е.А. Мехамадиев \\ Санкт-Петербургский государственный университет, \\ 199034, Санкт-Петербург, Российская Федерация, ул. Университетская набережная, д. 7/9 \\ E-mail: e.mehamadiev@spbu.ru
}

\begin{abstract}
Аннотация. Арабский географ Ибн ал-Факих, живший, судя по всему, во второй половине IX - начале X вв., в своем географическом трактате «Книга стран» упоминает о провинциях, которые входили в состав Византийской империи к началу $\mathrm{X}$ в. Среди этих провинций географ называет и Халдию с центром в Трапезунде, располагавшуюся на северо-востоке Малой Азии. Соответственно, автор данной статьи ставит вопрос, как возникла эта провинция, когда и при каких обстоятельствах, более того - как менялся административно-правовой статус этой провинции. На основании сведений различных источников, как греко-латинских (печати, упоминающие чиновников Халдии, письмо императора Михаила II, правившего в 820-829 гг.), так и грузинских (хроники и жития, переведенные на русский и современные западноевропейские языки), автор пришел к выводу, что провинция Халдия как отдельная территориальная единица империи была учреждена в период между 736 и 781 гг., тогда она обладала статусом гражданской провинции. В конце VIII в., в 790-х гг., эта провинция получила новый статус фемы - военнотерриториального округа, находившегося под властью стратига, этот наместник объединял в своих руках военные и гражданские полномочия.
\end{abstract}

Ключевые слова: Халдия, арабские географы, фемы, армия Армениак, царство Картли, Абхазия, коммеркиарий, стратиг.

Благодарности: исследование выполнено при финансовой поддержке РФФИ в рамках научного проекта № 20-09-00010.

Для цитирования: Мехамадиев Е.А. 2020. Арабский географ начала X в. Ибн ал-Факих о византийской феме Халдия: к вопросу о военной политике Константинополя в западно-кавказских и армянских владениях на рубеже VIII-IX вв. Via in tempore. История. Политология, 47 (4): 763-772. DOI: 10.18413/2687-0967-2020-47-4-763-772.

\section{An arabic geographer of the early $X^{\text {th }}$ c. Ibn al-Fakih about the Byzantine theme of Chaldia: on a military policy of Constantinople within its West Caucasus and Armenian possessions at the turn of the eighth - nineth centuries}

\author{
Evgeny A. Mekhamadiev \\ Saint-Petersburg State University \\ 7/9, Universitetskaya emb., Saint-Petersburg, 199034, Russia \\ E-mail: e.mehamadiev@spbu.ru
}

\begin{abstract}
An Arabic geographer Ibn al-Fakih, who lived, obviously, during the second half of the nineth - a beginning of the tenth centuries, mentions in his famous treatise «The Book of Countries» the provinces of Byzantine Empire, which constituted this Empire to the beginning of the tenth century. Among these provinces
\end{abstract}


the geographer enumerates the province of Chaldia with official centre in the city of Trapezund (modern Trabzon in Turkey), this province located at the North-West of Asia Minor. With this respect, the author of the present paper asks how, when and why this province was established, moreover, how an administrative rank of this region was changed. To answer this question the author turned to different sources, not only Greek-Latin (the seals, which mention the officials of Chaldia, a letter of the Emperor Michael II, who reigned in 820-829), but also the Georgian (chronicles and lives of saints translated to Russian and modern West Europe languages). Having based on this evidence, the author concluded that the province of Chaldia as a selfsufficient Byzantine territorial unit was established between 736 and 781, then it possessed a rank of a civil province. The reason of establishment of Chaldia was a devastating incursion of Arabic general Muhammad ibn Marwan in the West Caucasus regions, this incursion occurred just in 736-737 - during this campaign Muhammad ibn Marwan ravaged also many Byzantine West Caucasus possessions, including the fortress of Tsikhegoji (Archaeopolis) at the bank of Tekhura River. The Byzantines evacuated a garrison of this fortress and located these troops in Chaldia, troops were headed by two tourmarches, but a governor of the whole province was the so-called chief commerkiarios, a civil official. At the end of the eighth century, during the 790th, this province obtained a new rank of the theme - a military-administrative territorial district, a governor of this district was a military official called strategos, he combined two branches of power, that are military and civilian. The reason of such a conversion was an intention of Constantinople to stop a further territorial extending of the kingdom of Abchazia within West Caucasus lands and to prevent an invasion of Abchazian troops in Byzantine Minor Asia lands immediately.

Keywords: Chaldia, Arabic geographers, the themes, the army of Armeniakoi, the kingdom of Kartli, Abchazia, the kommerkiarios, the strategos.

Acknowledgments: The study was carried out with the financial support of the Russian Foundation for Basic Research within the framework of scientific project No. 20-09-00010.

For citation: Mekhamadiev E.A. 2020. An arabic geographer of the early $\mathrm{X}^{\text {th }}$ c. Ibn al-Fakih about the Byzantine theme of Chaldia: on a military policy of Constantinople within its West Caucasus and Armenian possessions at the turn of the eighth - nineth centuries. Via in tempore. History and political science, 47 (4): 763-772 (in Russian). DOI: 10.18413/2687-0967-2020-47-4-763-772.

Арабский географ Ибн ал-Факих - один из тех многочисленных авторов эпохи древности и Средневековья, о которых известно только благодаря их трудам. Этот автор не упоминается ни в одном ином произведении арабской географической и исторической литературы, соответственно, у исследователей нет сведений о его жизни, кроме одного важного факта - в 903 г. Ибн ал-Факих написал свой географический трактат «Книга стран», который дошел до наших дней только в сокращенной версии, составленной уже в XI в. другим автором [Meisami, Starkey, 1998, p. 323-324, sv. Ibn al-Faqīh].

Как и многие произведения арабской географической литературы, трактат Ибн алФакиха содержит сведения не только о землях Арабского халифата, но и о сопредельных странах, в том числе о Византии, с которой арабы постоянно воевали начиная с VII в. В главах, посвященных Византии, Ибн ал-Факих довольно подробно рассказывает об административно-территориальной организации империи, и в рамках данного сюжета он перечисляет те провинции, которые входили в состав Византии. Среди этих провинций арабский географ упоминает Халдию - регион с центром в городе Трапезунд (современный Трабзон в Турции) на северо-востоке Малой Азии, территориально Халдия располагалась вблизи Абхазии (или Авасгии) - первоначально автономного княжества, а затем и независимого царства на северо-западном побережье Черного моря, в основном земли Абхазии находились между реками Бзыбь (впадает в Черное море в районе Пицунды) и Гумиста (впадает в Черное море в районе Сухуми) [Nicholson, 2018, p. 1-2, sv. Abasgia].

В 1901 г. Э. Брукс перевел фрагменты данного трактата, где Ибн ал-Факих перечисляет византийские провинции, на английский язык, соответственно, цитируем фрагмент текста, содержащий сведения о Халдии, по переводу Э. Брукса: Next there adjoints it the province of Galdiya [Chaldia]... and the seat of the imtratighus is Ikrita... and with him are 
two turmukhs («далее располагается провинция Галдийя [Халдия]... и резиденция имтратига - Икрита... и вместе с ним два турмуха») [Brooks, 1901, p. 76]. Конечно же, под терминами «турмух» и «имтратиг» следует понимать византийские военные должности турмарха и стратига соответственно; другими словами, Халдию возглавлял наместник в должности стратига, которому подчинялись два турмарха, турмархи же, в свою очередь, возглавляли турмы - внутренние территориальные единицы Халдии, сами турмархи занимали более низкий ранг в административной иерархии империи, чем стратиги [Kazhdan, 1991, p. 2100-2101, sv. tourma, tourmarches].

Византийский административный справочник, известный под условным названием «Тактикон Успенского» (назван в честь его первоиздателя, русского византиниста

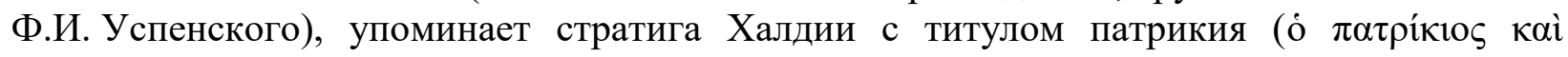

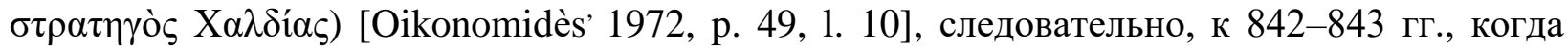
был составлен «Тактикон Успенского» [Oikonomidès, 1972, p. 47], Халдия обладала статусом фемы, т. е. военного административно-территориального округа, находившегося под властью стратига, стратиг каждой фемы занимал придворный ранг (титул) патрикия ${ }^{43}$.

Современная историография в лице Дж. Хэлдона придерживается вывода, что фемы как военно-административные округа были созданы в Малой Азии в начале IX в., при императоре Никифоре I (802-811 гг.), - по мнению исследователя, именно Никифор I учредил фемы, преобразовав старые гражданские провинции, существовавшие в Малой Азии еще со времен поздней Античности. Как проследил Дж. Хэлдон, Никифор упразднил старые провинции и объединил их в более крупные территориальные округа - фемы, во главе каждой фемы был поставлен стратиг, который выполнял не только военные, но и гражданские полномочия, т. е. совмещал в себе и функции командующего войсками, располагавшимися на территории фемы, и функции ее гражданского наместника [Brubaker, Haldon, 2011, p. 749-752, 755, 764, 769; Haldon, 2016, p. 246, 250, 254-255, 258-261].

Следовательно, с учетом позиции Дж. Хэлдона, мы можем предположить, что со времени правления Никифора I фемы были основной единицей внутреннего, административно-территориального деления Византии в Малой Азии, а значит, к 842-843 г. Халдия как регион, располагавшийся в Малой Азии, представляла собой именно фему. В таком случае возникает вопрос, когда возникла фема Халдия и всегда ли Халдия как регион была фемой, т. е. обладала ли эта территория статусом фемы изначально, с того самого момента, когда она была создана как отдельная территориальная единица империи?

Для ответа на этот вопрос, в первую очередь, обратим внимание на письмо императора Михаила II (820-829 гг.) к императору франков Людовику I Благочестивому, сыну Карла Великого, - письмо было написано и отправлено в Паризий (Париж), где проходил поместный церковный собор, в 824 г.; тем не менее текст письма сохранился только в латинском переводе. В данном письме, помимо обсуждения ряда богословских вопросов, Михаил II сообщает Людовику I о подавлении восстания Фомы Славянина - мятежного командующего группой византийских войск, который провозгласил себя императором в 821 г., но был разгромлен в 823 г. Согласно тексту письма, Фома Славянин «путем грабежа присоединил к себе весь округ Армении вместе с округом Халдии, народ которой населяет Кавказские горы, а также одержал победу над предводителем Армениаков и (его) сильным войском» (direptione sibi subdidit totum Armoeniae ducatum, simul et ducatum Chaldeae, quae gens montem Caucasum incolit, necnon et ducem Armeniacorum cum manu valida devicit) [Werminghoff, 1908, p. 476, 1. 23-24].

П. Лемерль пришел к выводу, что под термином ducatum, который мы переводим нейтральным словом «округ», следует понимать фему; по мнению П. Лемерля, слово ducatum было латинским переводом греческого слова $\theta \dot{\varepsilon} \mu \alpha$. Как полагал исследователь,

${ }^{43}$ Аргументы в пользу того, что «Тактикон Успенского» перечисляет именно фемы, см.: [Zuckerman, 2005, p. 132]. 
текст письма имеет в виду две фемы, Армениак и Халдию, Халдия же представляла собой новую фему, выделенную из фемы Армениак и преобразованную в самостоятельный военно-административный округ. По мнению П. Лемерля, выделение территории Халдии из состава фемы Армениак произошло до 824 г., во всяком случае, к 824 г. фема Халдия уже существовала [Lemerle, 1965, p. 286, n. 119].

Во многом под влиянием тезиса П. Лемерля в последующей исследовательской литературе утвердилась мысль о том, что фема Халдия была либо основана в 824 г., либо уже существовала к 824 г. [Bryer, Winfield, 1985, p. 301; Belke, 1996, S. 74]; естественно, подобная трактовка полностью зависит только от текста письма Михаила II. Тем не менее, на основании сведений жития Або Тбилели, грузинского святого арабского происхождения, жившего в VIII в., Б. Мартен-Исар пришла к выводу, что фема Халдия была учреждена на рубеже VIII-IX вв.; по мнению исследовательницы, целью создания данного военного округа с центром в Трапезунде было стремление византийской администрации остановить экспансию и продвижение Абхазского царства на территорию восточного побережья Черного моря [Martin-Hisard, 1981, p. 155-156].

Житие Або Тбилели (т. е. Тбилисского), по мнению П. Питерса и К. Кекелидзе, подготовивших латинский и русский переводы с грузинского оригинала, было написано в 786 г. [Peeters, 1934, p. 30; Кекелидзе, 1956, с. 32], т. е. задолго до 824 г. Как сообщает текст жития, в 781 г. ${ }^{44}$ Або Тбилели прибыл в Абхазию, на границе с которой располагалась область под названием Халдия («... до пределов Халдии; в ней находятся Трапезунд, поселение Апсар и гавань Нафсай, тамошние города и селения являются достоянием иаря христолюбивых греков») ${ }^{45}$.

Т. о., само наименование (топоним) «Халдия» впервые появилось задолго до 824 г., просто в 824 г. данный топоним впервые упоминается в греко-латинских источниках, тогда как авторам из стран и регионов Южного Кавказа наименование «Халдия» было известно уже с рубежа VIII-IX вв. Автор жития Або Тбилели четко фиксирует и осознает административную связь Халдии с Византией; согласно житию, эта территория входила в состав Византии. Другой вопрос, что, к сожалению, житие не уточняет, каким именно правовым статусом обладала территория Халдии в составе империи, на наш же взгляд, первоначально она представляла собой одну из провинций армии Армениак, т. е. в Халдии располагались некоторые войсковые подразделения этой армии (в 809 г. те регионы, где размещались наиболее крупные гарнизоны этой армии, т. е. Каппадокия, Пафлагония, Эленопонт, были объединены в новый территориальный округ - фему Армениак). Административным центром Халдии был город Трапезунд; очевидно, там размещался соответствующий войсковой гарнизон.

Судя по всему, к 824 г. провинция Халдия получила статус фемы; тем не менее, на наш взгляд, под сведениями текста жития Або Тбилели все же следует понимать небольшой территориальный округ (провинцию), входивший в состав более крупного региона

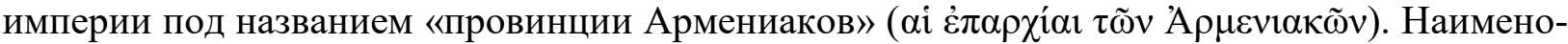
вание «провинции Армениаков» впервые упоминается в печати из коллекции Г. Закоса, датированной 717-718 гг.; судя по всему, под данными провинциями мы можем понимать регионы, где размещались крепости (гарнизоны) армии византийской армии Армениак, по сути - те регионы, где находились войсковые подразделения этой армии: «... главных коммеркиариев апотеки Колонии и всех провинций Армениака, любящего Христа. 1 ин-

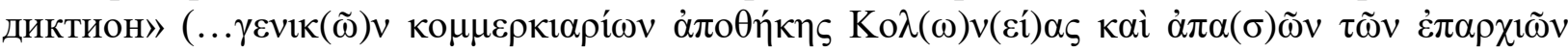

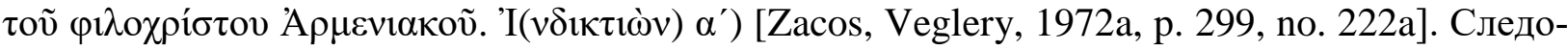
вательно, возникает вопрос, каким статусом обладали эти провинции, что они собой представляли - военные или гражданские регионы?

${ }^{44}$ В вопросе датировки следуем позиции К. Кекелидзе: [Кекелидзе, 1956, с. 33].

${ }^{45}$ Цит. по русскому переводу К. Кекелидзе: [Кекелидзе, 1956, с. 50]. Ср. латинский перевод П. Питерса: usque ad fines Chaldiae. Illic sita est Trapezon, et mansio Apsarea, et portus Nicopsis. Pertinent autem istae urbes et loca ad imperium Christum amantis regis Graecorum [Peeters, 1934, p. 26]. 
Еще в 1984 г. Р.-И. Лили пришел к выводу, что провинции Армениака, равно как и других армий (Опсикий, Анатолик), упоминаемые в печатях, представляли собой старые гражданские провинции, существовавшие еще со времен поздней Античности; соответственно, как заключил исследователь, применительно к армии Армениак под сведениями печатей следует понимать провинции Каппадокия, Пафлагония и Эленопонт, где размещалась основная масса войск этой армии [Lilie, 1984, S. 34]. Мы согласны с точкой зрения исследователя дело в том, что коммеркиарии, которые упоминает текст печати, представляли собой чиновников налоговой службы империи, в основном они выполняли две функции - собирали налоги с гражданского населения и снабжали войсковые гарнизоны продовольствием [Brandes, 2002, S. 421, 425; Montinaro, 2013, p. 400-401, 415, 417-418]; соответственно, полномочия определенной группы коммеркиариев распространялись сразу на несколько провинций. Другими словами, географический ареал действия определенной группы коммеркиариев, размещавшейся в продовольственном складе (амбаре) под названием «апотека», охватывал сразу несколько провинций; можно даже сказать, что в правовом и административном смыслах несколько провинций были закреплены за одной апотекой, точнее, эта апотека снабжала войсковые гарнизоны, располагавшиеся в нескольких провинциях.

Одной из таких провинций, где находились подразделения армии Армениак, была и Халдия - именно Халдия ближе всего располагалась к основным провинциям армии Армениак, поэтому вполне логично предположить, что и она тоже стала базой для размещения войск данной армии. Из сведений жития Або Тбилели мы можем сделать вывод, что провинция Халдия существовала уже к 781 г., когда вблизи ее земель разместился и сам святой. Следовательно, возникает новый вопрос - когда именно возникла эта провинция, с какими обстоятельствами был связан факт ее создания и каким статусом она все же обладала - военным или гражданским, т. е. какой чиновник возглавлял этот регион?

Для ответа на эти вопросы обратимся к грузинским источникам (хроники и жития), которые сохранили ценные сведения о взаимоотношениях Византии, Абхазии и царства Картли (восточная Грузия, бассейн реки Кура) во 2-й пол. VIII в. «Мученичество царя Арчила» - агиографический текст, написанный в XI в. Леонтием Мровели, епископом города Руиси в Грузии, повествует о мученической смерти царя Картли Арчила II, правившего, как установил К. Туманов, в 736-786 гг. [Toumanoff, 1963, p. 345, 352, 395, 403] ${ }^{46}$. Арчил погиб в 786 г. от рук арабов, вторгнувшихся в Картли и пытавшихся заставить его отказаться от христианства и принять ислам - после безуспешных попыток арабы казнили Арчила за его приверженность к христианской вере. Согласно тексту жития, когда командующий арабскими войсками Азим потребовал, чтобы Арчил сообщил, где спрятаны сокровища его царского рода, царь Картли ответил: «Мой отец и брат поместили все свои сокровища в крепости, от которой отступил эмир Глухой (арабский полководец и халиф Мухаммед ибн Марван II, жил в 688-750 гг., его прозвище в грузинских источниках «Глухой»-E.M.). Сейчас она находится во владении Греков» ${ }^{47}$.

Мы полагаем, что Леонти Мровели (или источник, сведениями которого он воспользовался) имеет в виду военный поход Мухаммеда ибн Марвана против царства Картли и его союзников на южном Кавказе, состоявшийся в 736-737 гг. [Mikaberidze, 2007, p. 449, sv. Marwan ibn-Muhammad]. В ходе этого похода Марван разграбил многие земли западной Грузии, в том числе и Абхазию, но в решающем сражении у крепости Анакопия Арчил и его союзник, князь (эристав) Абхазии Леон I, нанесли арабским войскам поражение и заставили их отступить [Mikaberidze, 2007, p. 449, sv. Marwan ibn-Muhammad]. Тем не менее другой источник, на этот раз хроника псевдо-Джуаншера (принятое в науке

${ }^{46}$ В современной историографии позицию К. Туманова поддерживает C. Рапп: [Rapp, 2003, p. 443, $472,474,478]$.

47 Цитируем текст по английскому переводу Р. Томсона: «My father and brother placed all their treasures in the fortress from which the emir Qru retreated. Now it is in the possession of the Greeks» [Thomson, 1996, p. 253]. 
условное обозначение неизвестного автора, скрывавшегося под именем Джуаншера Джуаншериани, другого грузинского хрониста, жившего в VIII в. [Toumanoff, 1943, p. 169-170], также этот автор известен под именем «продолжатель Джуаншера»), сообщает, что отец и брат Арчила зарыли сокровища своего рода «в Кутаиси и Цихе-Годжи» [Джуаншер Джуаншериани, 1986, с. 103]. Под крепостью Цихе-Годжи, конечно же, следует понимать Археополис - столицу древнего царства Лазика, располагавшегося на северозападе Грузии, в бассейне реки Риони (Фасис, как ее называли греки), территория самого Археополиса примерно соответствовала современному селу Нокалакеви в Грузии, на берегу реки Техури [Mikaberidze, 2007, p. 136, sv. Archaeopolis].

Псевдо-Джуаншер отмечает, что Марван «разрушил трехстенную крепость ЦихеГоджи, разгромил и прошел порубежсню стену Клисуры... И, как только прошел Глухой (т. е. Марван - E.M.), Клисуру, которая была в ту пору рубежом между Грецией и Грузией, разгромил город Апшилети Цхуми (современный Сухуми, столица Абхазии - E.M.) [Mikaberidze, 2007, p. 133, sv. Arabs, in Georgia] и подступил к крепости Анакопии» [Джуаншер Джуаншериани, 1986, с. 102-103], у стен этой крепости он в итоге и был разгромлен войсками Арчила и Леона I. Далее, как сообщает псевдо-Джуаншер, уже после победы над Марваном, Арчил отправил Леону письмо с благодарностью за помощь в борьбе с арабами, в этом письме грузинский царь подчеркнул, что «восстановлены владения наши выше от Клисуры. Пойду и устроюсь в Цихе-Годжи и Кутаиси». Наконец, устроив все эти дела, Арчил, со слов хрониста, «построил крепость на рубеже Гурии и Греции» [Джуаншер Джуаншериани, 1986, c. 106]; под Гурией, судя по всему, можно понимать историческую область в западной Грузии, располагавшуюся между реками Чорох (на юге, впадает в Черное море вблизи Батуми в современной Аджарии) и Риони (на севере) [Mikaberidze, 2007, p. 346, sv. Guria].

Наконец, еще один источник - «Мученичество Давида и Константина», двух князей (мтаваров), располагавшихся в княжестве (мтаварстве) Аргвети на западе Грузии (на землях этого княжества сегодня размещаются города Чиатура, Зестафони, Сачхере, Харагаули, в целом земли Аргвети простирались от Лихского хребта до Сухуми) - сообщает, что до своего поражения в битве при Анакопии Марван «забрал крепости и города, разорил их и сделал непроходимыми и безлюдными страну Мегрельскую и Абхазскую... и прошел (вдоль) морского берега и забрал крепости и города приморские» ${ }^{48}$.

Несмотря на то, что грузинские источники дают весьма противоречивую картину событий, на основании их сведений мы все же можем сделать несколько выводов:

1. Судя по всему, вплоть до 736 г. владения Византии на территории западного Кавказа простирались вплоть до крепости Цихе-Годжи, т. е. древнего Археополиса, на берегу реки Техури, не случайно Леонти Мровели в своем труде «Мученичество царя Арчила» утверждает, что крепость, где родственники Арчила спрятали сокровища царского рода, находилась под контролем греков, т. е. византийцев. Другой вопрос, что Византия утратила контроль над этой крепостью и ближайшими к ней землями не в 786 г., как говорит Леонти Мровели, а в 736 г. в результате грабительского похода Марвана и боевых действий грузино-абхазских войск против арабов.

2. Когда грузино-абхазские войска разгромили Марвана, Византия, судя по всему, заключила с царем Арчилом договор о разграничении сфер влияния - крепость ЦихеГоджи и соседние с ней земли вплоть до реки Чорох отошли к грузинскому царю, в то время как земли за рекой Чорох остались под контролем Византии.

Мы полагаем, что земли, оставшиеся под властью Византии и простиравшиеся от реки Чорох до города Трапезунд, как раз и были преобразованы в отдельную провинцию под названием «Халдия», в этой провинции разместились те византийские войска, кото-

${ }^{48}$ Цит. по русскому переводу Г.В. Цулая: [Цулая, 1996, с. 113-114]. По оценке Г.В. Цулая, этот текст был создан во времена правления грузинского царя Баграта IV (1027-1072 гг.), т. е. в XI в. [Цулая, 1996, c. 105]. 
рые ранее находились в крепости Цихе-Годжи и окружавших ее местностях. Не случайно Ибн ал-Факих, цитированный ранее, говорит о наличии в Халдии двух турмархов - очевидно, военное командование над войсками, перемещенными из Цихе-Годжи в Халдию, осуществляли два турмарха. Мы можем предположить, что сами войска, прибывшие в Халдию, в административно-правовом плане принадлежали к армии Армениак, входили в ее состав, соответственно, территория Халдии стала одной из провинций армии Армениак, т. е. в Халдии размещались гарнизоны (войсковые подразделения) данной армии.

Тем не менее, на наш взгляд, в тот период, т. е. в 736-781 гг., Халдия была не военной, а гражданской провинцией, ее возглавлял гражданский наместник; сведения печатей позволяют предположить, что функции гражданского управления находились в руках чиновника в должности главного коммеркиария, этот чиновник упоминается в печати из

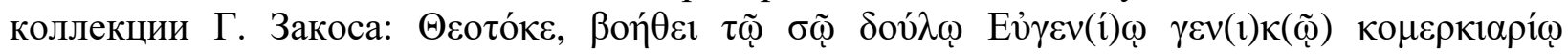

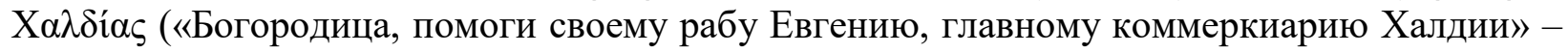
[Zacos, Veglery, 1972b, p. 1064, nо. 1880], датировка - IX в.). Очевидно, в период до 824 г., когда Халдия уже совершенно точно обладала статусом фемы, эту провинцию возглавлял главный коммеркиарий, после же 824 г. в течение какого-то времени он еще продолжал выполнять свои полномочия, несмотря на наличие в Халдии ее собственного стратига, т. е. военного наместника; другими словами, главный коммеркиарий и стратиг Халдии еще какое-то время сосуществовали друг с другом. Судя по всему, до 824 г. основными функциями главного коммеркиария Халдии были сбор налогов, снабжение войсковых гарнизонов провинции, а также судопроизводство, тогда как функции непосредственного военного командования над гарнизонами осуществляли два турмарха.

Соответственно, итоговый вопрос нашего исследования - когда именно Халдия превратилась из гражданской провинции в фему, т. е. когда возникла должность стратига Халдии, когда он встал во главе этого региона и какие причины заставили центральную администрацию империи провести такую реформу? Для ответа на поставленный вопрос обратимся к сведениям жития Георгия Амастридского, знаменитого византийского святого и епископа города Амастрида в Пафлагонии. Как известно, Георгий жил в период примерно с 750-760 до 802-807 гг.; около 790 г. патриарх Тарасий назначил Георгия епископом Амастриды [Kazhdan, 1991, p. 837, sv. George of Amastris]. Текст жития содержит рассказ о том, как Георгий, уже занявший епископскую кафедру, вызволил из темницы нескольких торговцев Амастриды, ложно обвиненных в торговых злоупотреблениях и заключенных под стражу в

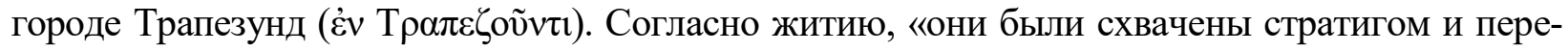

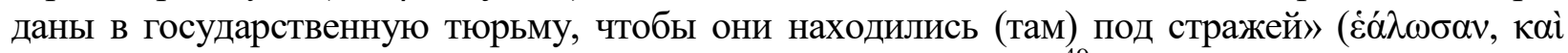

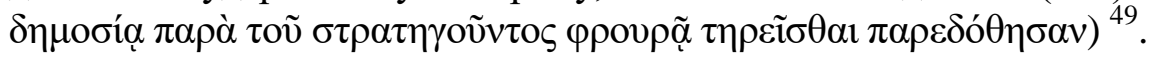

А. Брайер и Д. Уинфилд отождествили стратига, упоминаемого в житии Георгия Амастридского, со стратигом Халдии [Bryer, Winfield, 1985, p. 301], и мы поддерживаем трактовку исследователей, другой вопрос - из текста жития четко видно, что этот стратиг занимался вопросами судопроизводства, а значит, он осуществлял полномочия гражданской власти. Следовательно, мы можем предположить, что в период между 790 и 802-807 гг. центральная администрация Византии преобразовала Халдию в фему - во главе этого региона был поставлен стратиг, который теперь выполнял и функции гражданского наместника, одновременно он осуществлял командование и над двумя турмархами, располагавшимися ранее в Халдии. Судя по всему, функции главного коммеркиария теперь ограничивались исключительно сбором налогов.

По какой причине центральная администрация приняла решение учредить должность стратига Халдии? Мы полагаем, что такой причиной было резкое усиление Абхазии в 790-е гг., расширение ее территориальных пределов - согласно хронике «Летопись Картли», «Когда же ослабли греки, отложился от них эристав абхазский по имени Леон, племянник

${ }^{49}$ Цит. по: [Васильевский, 1915, с. 42]. 
эристава Леона, которому дана была в наследство Абхазия. Сей второй Леон был сыном дочери хазарского изаря, и с помощьью его и отложился он (Леон) от греков, присвоил Абхазию с Эгриси до самого Лихи и нарекся иарем абхазов» ${ }^{50}$. Конечно же, под этим Леоном, племянником другого Леона, следует понимать князя (эристава) Абхазии Леона II, правившего с 758 по 798 гг. [Mikaberidze, 2007, p. 425, sv. Leon II], который провозгласил себя царем Абхазии и присоединил к своим владениям практически все регионы современной западной Грузии, тем самым он продвинулся непосредственно к границам Византии, т. е., фактически - к землям провинции Халдия. Как показали К. Туманов и С. Рапп, Леон II провозгласил себя царем и присвоил себе земли западной Грузии в 790-е гг. [Toumanoff, 1963, p. 256, 401, note 45, 411, note 22; Rapp, 2003, p. 483]; следовательно, мы можем заключить, что два процесса - создание фемы Халдия и резкое усиление (а также территориальное расширение) Абхазии практически полностью совпали друг с другом по времени.

Это совпадение, в свою очередь, наводит на мысль, что гражданская провинция Халдия была преобразована в военный округ (фему) именно в связи с опасностью, исходившей от Абхазского царства - византийцы стремились преградить путь для дальнейшего продвижения Леона II уже непосредственно в земли Малой Азии, поэтому они поспешили разместить в Халдии стратига и вместе с ним, очевидно, и группу новых войск, усилив тем самым старые гарнизоны региона. Фактически мы можем признать, что фема Халдия была учреждена даже раньше, чем другие фемы Малой Азии, т. е. в 790-е гг., задолго до реформ Никифора I, учредившего большие фемы, такие как Армениак, Анатолик и Опсикий.

\section{Список литературы}

1. Васильевский В.Г. 1915. Житие св. Георгия Амастридского (тексты русский и греческий). В кн.: Васильевский В.Г. Труды. Том III. Петроград, Типография Императорской Академии наук: $1-71$.

2. Джуаншер Джуаншериани. 1986. Жизнь Вахтанга Горгасала. Пер. Г.В. Цулая. Тбилиси, Мецниереба, 149.

3. Летопись Картли. Пер. Г.В. Цулая. Тбилиси, Мецниереба, 1982.

4. Памятники древнегрузинской агиографической литературы. Пер. К. Кекелидзе. Тбилиси, Академия наук Грузии, 1956.

5. Цулая Г.В. 1996. Из истории грузинской агиографии: «Мученичество Давида и Константина». Этнографическое обозрение, (№ 1): 104-116.

6. Belke K. 1996. Paphlagonien und Honōrias. Wien, Verlag der Österreichischen Akademie der Wissenschaften (Tabula Imperii Byzantini, 9), 327.

7. Brandes W. 2002. Finanzverwaltung in Krisenzeit. Untersuchungen zur byzantinischen Administration im 6-9 Jahrhundert. Frankfurt a/Main, Löwenklau-Gesellschaft, 788.

8. Brooks E.W. 1901. Arabic Lists of the Byzantine Themes. JHS, 21: 67-77.

9. Brubaker L., Haldon J. 2011. Byzantium in the Iconoclast Era, c. 680-850: a History. Cambridge, Cambridge University Press, 907.

10. Bryer A., Winfield D. 1985. The Byzantine Monuments and Topography of the Pontos. Vol. I. Washington D.C., Dambarton Oaks, 394.

11. Encyclopedia of Arabic Literature. Ed. by J.S. Meisami and P. Starkey. Vol. I. London - N.Y, Roudledge., 1998.

12. Haldon J. 2016. A context for two «evil deeds»: Nikephoros I and the origins of the themata. In: Le saint, le moine et le paysan. Mélanges d'histoire byzantine offerts à Michel Kaplan. Éd. par O. Delouis, S. Métivier et P. Pagès. Paris, Publications de la Sorbonne: 245-265.

13. Lemerle P. 1965. Thomas le Slave. TM, 1: 255-298.

14. Lilie R.-J. 1984. Die zweihundertjährige Reform. Zu den Anfängen der Themenorganisation im 7 und 8 Jahrhundert. I. Die «Reform» der Verwaltung. BS, 45 (1): 27-39.

15. Martin-Hisard B. 1981. La domination byzantine sur le littoral oriental du Pont Euxin (milieu du VII-VIII siècles). Byzantino-Bulgarica, 7: 141-156.

\footnotetext{
${ }^{50}$ Цит. по русскому переводу Г.В. Цулая: [Цулая, 1982, с. 48].
} 
16. Mikaberidze A. 2007. Historical Dictionary of Georgia. Maryland, The Scarecrow Press, 733.

17. Montinaro F. 2013. Les premiers commerciaires Byzantins. TM, 17: 351-538.

18. Monumenta Germaniae historica. Legum sectio III. Concilia. Tomus II: Concilia aevi Karolini I. Pars II. Ed. A. Werminghoff. Hannoverae-Lipsiae, Impensis Bibliopolii Hahniani, 1908.

19. Oikonomidès N. 1972. Les listes de préséance byzantines des $\mathrm{IX}^{\mathrm{e}}$ et $\mathrm{X}^{\mathrm{e}}$ siècles. Paris, Centre National de la Recherche Scientifiques, 403. Press, 1991.

20. Oxford Dictionary of Byzantium. Ed. By A. Kazhdan. Vol. 1-3. Oxford, Oxford University

21. Peeters P. 1934. Les Khazars dans la Passion de S. Abo de Tiflis. AB, 52 (1/2): 21-56.

22. Rapp St. 2003. Studies in Medieval Georgian Historiography: Early Texts and Eurasian Contexts. Louvain, Peeters, 522.

23. Rewriting Caucasian History. The Medieval Armenian Adaptation of the Georgian Chronicles. The Original Georgian Texts and the Armenian Adaptation. Transl. with Introduction and Commentary by R.W. Thomson. Oxford, Clarendon University Press, 1996.

24. The Oxford Dictionary of Late Antiquity. / Ed. by O. Nicholson. Vol. I: A-I. Oxford, Oxford University Press, 2018.

25. Toumanoff C. 1943. Medieval Georgian Historical Literature (VII-XV Centuries). Traditio, 1: $139-182$.

26. Toumanoff C. 1963. Studies in Christian Caucasian History. Georgetown, Georgetown University Press, 600.

27. Zacos G., Veglery A. 1972a. Byzantine Lead Seals. Vol. I/1. Nos. 1-1095. Basel, J.J. Augustin, 704.

28. Zacos G., Veglery A. 1972b. Byzantine Lead Seals. Vol. I/2. Nos. 1096-2671A. Basel, J.J. Augustin, 729 .

29. Zuckerman C. 2005. Learning from the Enemy and More: Studies in «Dark Centuries» Byzantium. Millenium, 2: 79-136.

\section{References}

1. Vasil'evskiy V.G. 1915. Zhitiye sv. Georgiya Amastridskogo (teksty russkiy i grecheskiy) [The Life of George of Amastris (Russian and Greek Texts)]. In: Vasil'evskiy V.G. Trudy [Works]. Vol. III. Petrograd, Imperial Academy of Sciences Publ.: 1-71 (in Russian).

2. Dzhuansher Dzhuansheriani. 1986. Zhizn' Vakhtanga Gorgasala, perevod G.V. Tsulaya [The Life of Vakhtang Gorgasali translated by G.V. Tsulaya]. Tbilisi, Metsniereba Publ., 149 (in Russian).

3. Letopis' Kartli [The Chronicle of Kartli]. Tsulaya G.V. (translation of). 1982. Tbilisi, Metsniereba Publ., 112 (in Russian).

4. Pamyatniki drevnegruzinskoy agiograficheskoy literatury [Sources for Ancient Greek Hagiography Literature]. Kekelidze K. (translation of). 1956. Tbilisi, Georgian Academy of Sciences Publ., 106. (in Russian).

5. Tsulaya G.V. 1996. Iz istorii gruzinskoy agiografii: «Muchenichestvo Davida i Konstantina» [From a History of Georgian Hagiography: «A Martyrdom of David and Constantine»]. Etnograficheskoye obozreniye [Ethnographical Review], 1: 104-116 (in Russian).

6. Belke K. 1996. Paphlagonien und Honōrias. Wien, Verlag der Österreichischen Akademie der Wissenschaften (Tabula Imperii Byzantini, 9), 327.

7. Brandes W. 2002. Finanzverwaltung in Krisenzeit. Untersuchungen zur byzantinischen Administration im 6-9 Jahrhundert. Frankfurt a/Main, Löwenklau-Gesellschaft, 788.

8. Brooks E.W. 1901. Arabic Lists of the Byzantine Themes. JHS, 21: 67-77.

9. Brubaker L., Haldon J. 2011. Byzantium in the Iconoclast Era, c. 680-850: a History. Cambridge, Cambridge University Press, 907.

10. Bryer A., Winfield D. 1985. The Byzantine Monuments and Topography of the Pontos. Vol. I. Washington D.C., Dambarton Oaks, 394.

11. Encyclopedia of Arabic Literature. Ed. by J.S. Meisami and P. Starkey. Vol. I. London - N.Y, Roudledge., 1998.

12. Haldon J. 2016. A context for two «evil deeds»: Nikephoros I and the origins of the themata. In: Le saint, le moine et le paysan. Mélanges d'histoire byzantine offerts à Michel Kaplan. Éd. par O. Delouis, S. Métivier et P. Pagès. Paris, Publications de la Sorbonne: 245-265.

13. Lemerle P. 1965. Thomas le Slave. TM, 1: 255-298. 
14. Lilie R.-J. 1984. Die zweihundertjährige Reform. Zu den Anfängen der Themenorganisation im 7 und 8 Jahrhundert. I. Die «Reform» der Verwaltung. BS, 45 (1): 27-39.

15. Martin-Hisard B. 1981. La domination byzantine sur le littoral oriental du Pont Euxin (milieu du VII-VIII siècles). Byzantino-Bulgarica, 7: 141-156.

16. Mikaberidze A. 2007. Historical Dictionary of Georgia. Maryland, The Scarecrow Press, 733.

17. Montinaro F. 2013. Les premiers commerciaires Byzantins. TM, 17: 351-538.

18. Monumenta Germaniae historica. Legum sectio III. Concilia. Tomus II: Concilia aevi Karolini I. Pars II. Ed. A. Werminghoff. Hannoverae-Lipsiae, Impensis Bibliopolii Hahniani, 1908.

19. Oikonomidès N. 1972. Les listes de préséance byzantines des IXe et Xe siècles. Paris, Centre National de la Recherche Scientifiques, 403. Press, 1991.

20. Oxford Dictionary of Byzantium. Ed. By A. Kazhdan. Vol. 1-3. Oxford, Oxford University

21. Peeters P. 1934. Les Khazars dans la Passion de S. Abo de Tiflis. AB, 52 (1/2): 21-56.

22. Rapp St. 2003. Studies in Medieval Georgian Historiography: Early Texts and Eurasian Contexts. Louvain, Peeters, 522.

23. Rewriting Caucasian History. The Medieval Armenian Adaptation of the Georgian Chronicles. The Original Georgian Texts and the Armenian Adaptation. Transl. with Introduction and Commentary by R.W. Thomson. Oxford, Clarendon University Press, 1996.

24. The Oxford Dictionary of Late Antiquity. / Ed. by O. Nicholson. Vol. I: A-I. Oxford, Oxford University Press, 2018. 1: $139-182$.

25. Toumanoff C. 1943. Medieval Georgian Historical Literature (VII-XV Centuries). Traditio,

26. Toumanoff C. 1963. Studies in Christian Caucasian History. Georgetown, Georgetown University Press, 600 .

27. Zacos G., Veglery A. 1972a. Byzantine Lead Seals. Vol. I/1. Nos. 1-1095. Basel, J.J. Augustin, 704.

28. Zacos G., Veglery A. 1972b. Byzantine Lead Seals. Vol. I/2. Nos. 1096-2671A. Basel, J.J. Augustin, 729.

29. Zuckerman C. 2005. Learning from the Enemy and More: Studies in «Dark Centuries» Byzantium. Millenium, 2: 79-136.

\section{Список условных сокращений}

AB - Analecta Bollandiana. Bruxelles, 1882-

BS - Byzantinoslavica. Prague, 1929-

JHS - Journal of Hellenic Studies. London, 1880-

TM - Travaux et mémoires. Paris, 1965-

\section{ИНФОРМАЦИЯ ОБ АВТОРЕ}

Мехамадиев Евгений Александрович, кандидат исторических наук, старший преподаватель кафедры истории Средних веков Санкт-Петербургского государственного университета, г. Санкт-Петербург, Россия

\section{INFORMATION ABOUT THE AUTHOR}

Evgeny A. Mekhamadiev, Candidate of Historical Sciences, Senior Lecturer of the Department of History of the Middle Ages, St. Petersburg State University, St. Petersburg, Russia 